\title{
Evidence for a prolonged retroflection of the North Brazil Current during glacial stages
}

\author{
Katy E. Wilson ${ }^{\mathrm{a}, *}$, Mark A. Maslin ${ }^{\mathrm{a}}$, Stephen J. Burns ${ }^{\mathrm{b}}$ \\ a Department of Geography, University College London, Gower Street, London, WC1E 6BT, UK \\ ${ }^{\mathrm{b}}$ Department of Geosciences, University of Massachusetts, Amherst, 01002 Massachusetts, USA
}

\section{A R T I C L E I N F O}

Article history:

Received 20 September 2010

Received in revised form 5 January 2011

Accepted 6 January 2011

Available online 14 January 2011

\section{Keywords:}

North Brazil Current

Retroflection

Amazon freshwater plume

$\delta^{18} \mathrm{O}$ analysis

$\mathrm{Mg} / \mathrm{Ca}$ palaeothermometry

\begin{abstract}
A B S T R A C T
The importance of the role played by the tropics in driving and propagating climate change between hemispheres has long been the focus of attention in a bid to evaluate ocean-atmosphere interactions on glacial-interglacial timescales. The Amazon Fan and Ceara Rise in the western equatorial Atlantic Ocean lie directly in the flowpath of the North Brazil Current (NBC) which, as a conduit for the cross-equatorial transport of heat and salinity, is a key component for the heat budget of the North Atlantic. $\mathrm{Mg} / \mathrm{Ca}$ palaeothermometry and stable oxygen isotope analysis of planktonic foraminifera sampled from 15 sites across the Amazon Fan and Ceara Rise reveal variations in oceanic surface currents and of the dispersal of freshwater from the River Amazon over five timeslices (modern; early Holocene; Younger Dryas; Late Glacial and Marine Isotope Stage 3). Sea surface temperature reconstructions reveal progressive climatic amelioration over the last $\sim 30 \mathrm{ka}$, indicating a temperature increase of $\sim 3.2 \pm 1.1{ }^{\circ} \mathrm{C}$ since the Late Glacial. In conjunction with this warming, values of $\Delta \delta^{18} \mathrm{O}$, a proxy for water column stratification indicates increased vertical mixing of the glacial ocean. The spatial distribution of values of $\delta^{18} \mathrm{~W}$ (the isotopic composition of ambient seawater) is used to infer surface current variations and demonstrates an oceanward shift in the river outflow plume in cold climates representing a prolongation or possibly permanent continuation in the duration of the seasonal retroflection of the NBC causing the curtailment of cross-equatorial transport. A prolongation of this retroflection could have resulted from a mean southward migration of the southern boundary of the ITCZ.
\end{abstract}

(c) 2011 Elsevier B.V. All rights reserved.

\section{Introduction}

Large-scale temperature oscillations observed in oxygen isotope records from Greenland ice cores have been found to reflect extensive reorganisations of the ocean-atmosphere system over glacialinterglacial timescales (Bond et al., 1993). In the search for a mechanism to explain the processes governing such global changes, attention has increasingly focused on the tropics which, as a major source of sensible heat, latent heat and water vapour to the atmosphere, have the potential to alter oceanic balance by the export of heat and salinity to the high latitudes through thermohaline circulation (Broecker, 1997). As an important component of thermohaline circulation, the tropical Atlantic Ocean is an important driving force for climatic change and the accumulation of excess salt in this region ultimately impacts upon the density of high latitude surface waters which drive the formation of North Atlantic Deep Water (NADW). During glacial stages, an increased latitudinal thermal

\footnotetext{
* Corresponding author. Environmental Change Research Centre, Department of Geography, University College London, Pearson Building, Gower Street, London, WC1E 6BT, UK. Tel.: + 44207679 0532; fax: + 442076790565.

E-mail address: k.e.wilson@ucl.ac.uk (K.E. Wilson).
}

gradient is thought to have led to reduced penetration of the Intertropical convergence zone (ITCZ) - a convective belt of increased cloud and precipitation in tropical latitudes - into the northern hemisphere causing a decrease in the cross-equatorial transport of heat and salinity by upper-level ocean currents (Berger and Wefer, 1996; Maslin et al., 1997; Vink et al., 2002). In addition to observed seasonal shifts in the position of the ITCZ which determine the onset and duration of the tropical and subtropical wet seasons, palaeoclimate records reveal that a longer-term migration in the mean position of the ITCZ may have had a significant impact on the hydrological cycle (Dahl et al., 2005; Maslin and Burns, 2000).

In this study we present spatial and temporal reconstructions of variations in oceanic surface water currents from the Amazon Fan and Ceara Rise in the western equatorial Atlantic Ocean (Fig. 1). Surface water ocean circulation off the coast of northeastern Brazil is dominated by the dynamics of the North Brazil Current (NBC) which, as the only upper-level current to cross the equator, is important for the northward flux of heat and salinity to the Caribbean Sea and the North Atlantic. Lying directly in the trajectory of the NBC, the Amazon Fan provides an excellent palaeoclimate archive for investigating surface current variation during interglacial and glacial climate conditions and changes in freshwater dispersal from the River Amazon. 


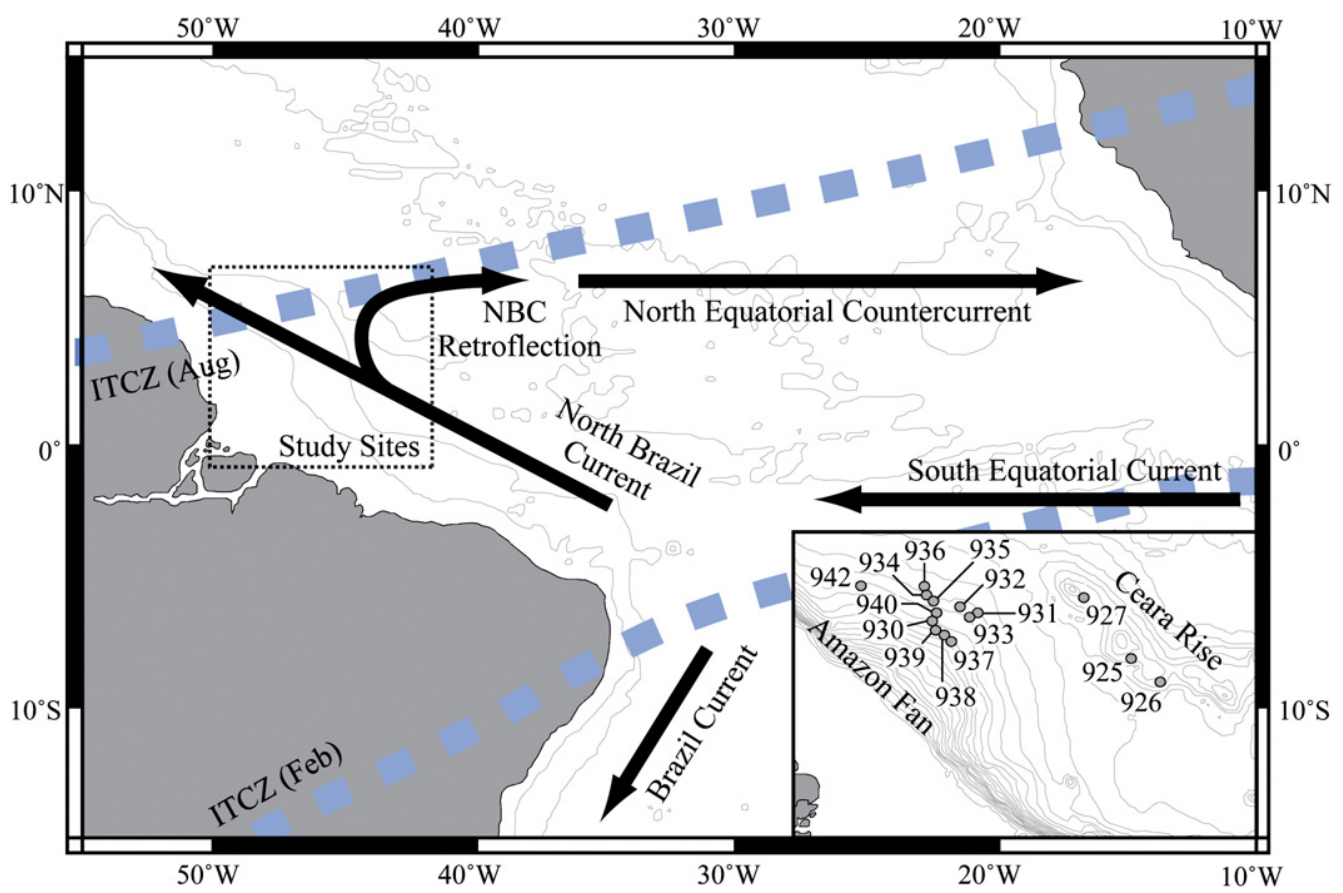

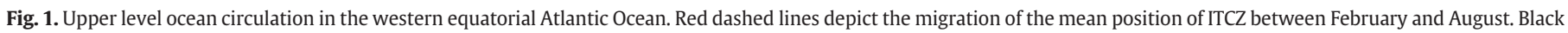
square indicates area enlarged in inset, showing site distribution across the Amazon Fan and Ceara Rise.

Maslin et al. (1997) suggest that long term changes in the annual duration of the NBC retroflection may be associated with colder climates. The reduction in heat transport caused by increased or even continual retroflection of the NBC has important implications for global ocean dynamics and thermohaline circulation. This hypothesis is supported by Rühlemann et al. (2001) who find that a weakening of the Gulf Stream during the Last Glacial Maximum (LGM) is concurrent with a prolongation of the NBC retroflection and curtailment of crossequatorial transport. A simple river-ocean mixing model adopted by Karr and Showers (2002) suggests that there is a linear mixing pattern between isotopically negative fresh river water and saline ocean water, with negligible modification by atmospheric processes. By assuming that more isotopically negative ice-volume corrected oxygen isotope values indicate a greater input of freshwater, we aim to reconstruct a spatial representation of changes in the dynamics of surface water currents over time.

\section{Regional setting}

\subsection{Oceanographic setting}

Upper level geostrophic currents in the western equatorial Atlantic are controlled by seasonal variations in the position of the ITCZ and wind-driven movement about the South Atlantic subtropical gyre (Berger and Wefer, 1996). Water flows along the equator as the South Equatorial Current (SEC) and bifurcates at the Brazilian continental margin into the southward-flowing Brazil Current and the northwestward-flowing North Brazil Current (NBC) which then merges with the North Brazil Undercurrent (Stramma et al., 1995). The NBC is a warm water western boundary current which is a conduit for the cross-equatorial transport of upper ocean water as part of the Atlantic meridional overturning cell. It acts to close the wind-driven equatorial gyre circulation and feeds a system of zonal counter-currents. As a consequence of the amount of water transported west by the SEC, a strong W-E pressure gradient develops, leading to the seasonal retroflection of the NBC and the formation of the North Equatorial Countercurrent (NECC) (Fig. 1). During boreal summer, the NBC turns eastwards at $7-8^{\circ} \mathrm{N}$ to form the NECC, reducing the volume of crossequatorial transport whilst between February and May, a weakening or even reversal of the NECC is coincident with increased NBC transport, due to wind stress variation resulting in a greater flux of heat and salinity to the northern hemisphere (Didden and Schott, 1993; Johns et al., 1998). Modelling studies have suggested that the flow pattern and intensity of northward heat and salinity transport is controlled by the strength of northeast trade winds associated with the seasonal southward displacement of the ITCZ (Wang et al., 2004).

The NBC also influences the dispersal and distribution of sediment and freshwater discharged from the River Amazon. The river contributes $6 \times 10^{12} \mathrm{~m}^{3}$ of freshwater to the Atlantic Ocean each year, representing approximately $16 \%$ of global oceanic discharge (Müller-Karger et al., 1988). The freshwater plume amplifies the high density stratification that is characteristic of the modern tropical water column in this area (Gibbs, 1970). River water is advected northwards by the NBC in a brackish plume, the dimensions of which are controlled by wind patterns and seasonal fluctuations in the amount of river outflow and the structure of the NBC (Didden and Schott, 1993). When the NBC retroflection is at its strongest (AugOct), almost $70 \%$ of the Amazon freshwater plume is transported eastwards towards the NECC (Rühlemann et al., 2001).

Deep water circulation in the western equatorial Atlantic Ocean is dominated by interactions between the southward flowing NADW and the northward flowing Circumpolar Deep Water (Bickert et al., 1997). As a result of the importance of interhemispheric heat and salinity exchange through thermohaline circulation, variations in the relative flux of the NADW to the Southern Ocean are thought to be a major driving force in the growth and decay of continental ice sheets (Harris et al., 1997).

\subsection{Climatic setting}

The Amazon Basin acts as a major heat source within the tropics generating an intense convection centre which impacts upon extratropical atmospheric circulation. Associated with the expansion and contraction of subtropical anticyclones over the North and South 
Atlantic Ocean, the seasonal migration of the ITCZ imposes distinctive wet and dry season across northern South America. The characteristic traits of the ITCZ do not exist over much of central Amazonia where continuously high temperatures of $24-28{ }^{\circ} \mathrm{C}$ combine with high transpiration rates to cause the region to act as a source of maritime equatorial air (Dürkoop et al., 1997). Due to its influence on ocean current dynamics, the migration of the ITCZ has a more marked effect on the climate of coastal regions. Convection and wind direction patterns, controlled largely by insolation changes, are associated with the equatorial low-pressure trough and the South American Summer Monsoon (SASM), which influences the timing of the onset of the wet season across South America.

During glacial periods, the ITCZ undergoes a mean southward migration which greatly alters the dynamics of regional climate within the Amazon Basin through changes to vegetation, continental run-off and river outflow patterns. Evidence from terrestrial records suggests that, during the LGM, temperatures were an average of $5{ }^{\circ} \mathrm{C}$ cooler (Table 1). Palaeomoisture reconstructions are more complex and reveal that there is a great deal of spatial variation across Amazonia; some records indicate increased aridity during the LGM (e.g. Behling and Hooghiemstra, 1999; Curtis et al., 1999) whilst others suggest that the Amazon Basin was wetter during this time (e.g. Bush et al., 2002; Colinvaux et al., 1996).

\subsection{Depositional setting}

The Amazon Fan is a deep-sea passive margin fan composed of a complex lithostratigraphic sequence of mass transport deposits, levee systems and hemipelagic sediments, overlain by a thin layer oxidized calcareous oozes. It developed as a result of rapid riverine sediment deposition since the Miocene uplift of the East Andean Cordillera (Damuth and Kumar, 1975; Figueiredo et al., 2009, 2010; Hoorn et al., 1995) however it has been shown that high sedimentation rates on the Amazon Fan began 2.4 Ma ago (Figueiredo et al., 2009). The sedimentary regime of the fan is linked to glacio-eustatic sea-level fluctuations such that during interglacial high stands, discharged sediment is trapped on the continental shelf and is transported northwestwards by longshore currents, starving the Amazon Fan of terrigenous input (Showers et al., 1997). Increased exposure of the continental shelf during glacial periods means that riverine terrigenous sediment is channeled directly onto the Fan via the Amazon submarine canyon (Damuth and Kumar, 1975). Whilst oceanic hemipelagic sedimentation is constant throughout, the biogenic component becomes heavily diluted during glacial episodes (Showers et al., 1997).

Formed approximately $80 \mathrm{Ma}$ ago, the Ceara Rise is an aseismic bathymetric ridge situated adjacent to the easternmost portion of the Amazon Fan (Bassinot et al., 1997) (Fig. 1). The sedimentary regime is primarily characterised by oceanic hemipelagic sedimentation in addition to a small proportion of terrestrially-derived lithogenic material. In a similar manner to the Amazon Fan, the input of terrigenous sediments is thought to be influenced by glacio-eustatic variations, local climate dynamics and seasonal hydrographic regimes (Curry et al., 1995; Rühlemann et al., 2001). 15 sites (Table 2) from Ocean Drilling Program (ODP) Leg 154 (3 sites) and Leg 155 (12 sites) were selected for this study on the basis of documented foraminiferal abundance and robust chronological control. Five time-slices representing the early Holocene ( $9 \mathrm{ka})$, Younger Dryas ( $11 \mathrm{ka})$, the Late Glacial (17.85 ka) and Marine Isotope Stage (MIS) 3 ( 32 ka) were selected in addition to core top (modern) samples in order to establish the extent of glacial-interglacial palaeoclimatic variations in the western equatorial Atlantic Ocean.

\section{Material and methods}

\subsection{Age models}

The lithostratigraphic positions of the five time-slices in sediment cores recovered from the 15 ODP sites were determined from preexisting age-depth models developed using a combination of

Table 1

Synthesis of published palaeotemperature reconstructions for northern South America and the western equatorial Atlantic Ocean.

\begin{tabular}{|c|c|c|c|c|c|}
\hline \multirow{2}{*}{\multicolumn{2}{|c|}{ Timeslice }} & \multicolumn{4}{|l|}{ Palaeotemperature reconstruction } \\
\hline & & Proxy & Location & Cooling estimate & Reference \\
\hline \multirow{3}{*}{\multicolumn{2}{|c|}{ MIS3 ( 30 ka) }} & Alkenone SST & SE. of Grenada, tropical Atlantic & $2.7^{\circ} \mathrm{C}$ & Rühlemann et al. (1999) \\
\hline & & Planktonic Foraminifera & Tobago Basin, Lesser Antilles & $4{ }^{\circ} \mathrm{C}$ & Hüls and Zahn (2000) \\
\hline & & & Tropical Atlantic Ocean & $3{ }^{\circ} \mathrm{C}$ & Vink et al. (2001) \\
\hline \multirow[t]{15}{*}{ Late Glacial ( 18 ka) } & \multirow[t]{8}{*}{ i). SST } & Planktonic Foraminifera & W. equatorial Atlantic & $2{ }^{\circ} \mathrm{C}$ & CLIMAP (1976) \\
\hline & & & Ceara Rise & $2-3^{\circ} \mathrm{C}$ & Wolff et al. (1998) \\
\hline & & & Equatorial Atlantic & $2{ }^{\circ} \mathrm{C}$ & Mix et al. (1999) \\
\hline & & & ODP Site 942, Amazon Fan & $3-3.75^{\circ} \mathrm{C}$ & Ettwein (2004) \\
\hline & & & Ceara Rise & $2-3{ }^{\circ} \mathrm{C}$ & Dürkoop et al. (1997) \\
\hline & & & W. coast of Brazil (Fortaleza) & $3-4^{\circ} \mathrm{C}$ & Arz et al. (1998) \\
\hline & & Benthic Foraminifera & Tropical Atlantic Ocean & $4{ }^{\circ} \mathrm{C}$ & Schrag et al. (1996) \\
\hline & & Corals & Barbados & $5{ }^{\circ} \mathrm{C}$ & Guilderson et al. (1994) \\
\hline & \multirow[t]{7}{*}{ ii). Terrestrial } & Pollen & W. coast of Brazil & $5-7{ }^{\circ} \mathrm{C}$ & Behling et al. (2002) \\
\hline & & & Lake Pata, Amazon Basin & $5-6{ }^{\circ} \mathrm{C}$ & Colinvaux et al. (1996) \\
\hline & & Forest Beds & Ecuador & $4-5^{\circ} \mathrm{C}$ & Liu and Colinvaux (1985) \\
\hline & & Noble Gases in Groundwater & Piaui Province, Brazil & $5.4 \pm 0.6^{\circ} \mathrm{C}$ & Stute et al. (1995) \\
\hline & & Palaeosols & Bogota Basin & $6 \pm 2{ }^{\circ} \mathrm{C}$ & Mora and Pratt (2001) \\
\hline & & Lake Sediments & Lake Junin and Lake Titicaca, Peru & $4-6{ }^{\circ} \mathrm{C}$ & Seltzer et al. (2002) \\
\hline & & Ice Core Records & Sajama, Bolivia and Huascarán, Peru & $\sim 8{ }^{\circ} \mathrm{C}$ & Thompson (2000) \\
\hline \multirow{3}{*}{\multicolumn{2}{|c|}{ Younger Dryas (11 ka) }} & Planktonic Foraminifera & Cariaco Basin & $3-4{ }^{\circ} \mathrm{C}$ & Lea et al. (2003) \\
\hline & & Ice Core Records (Sajama, Bolivia) & \multicolumn{2}{|c|}{$\begin{array}{l}\text { Cold conditions of the Deglacial Climate Reversal (DCR) } \\
\text { continued until } 11.5 \text { ka when rapid warming marks the } \\
\text { onset of the Holocene ( } T \text { similar to modern) }\end{array}$} & Thompson et al. (1998) \\
\hline & & Ocean-atmosphere model & \multicolumn{2}{|c|}{$\begin{array}{l}\text { Temperature change in W. tropical Atlantic and } \\
\text { Caribbean Sea is highly complex with warming in some } \\
\text { areas and cooling in others depending on dominant } \\
\text { physical processes }\end{array}$} & Wan et al. (2009) \\
\hline \multicolumn{2}{|l|}{ Early Holocene (9 ka) } & Planktonic Foraminifera (South of Amazon Fan) & \multicolumn{2}{|c|}{$\begin{array}{l}\text { Temperature reconstruction indicates a } 3-4{ }^{\circ} \mathrm{C} \text { shift } \\
\text { from the LGM-Holocene and a } 2{ }^{\circ} \mathrm{C} \text { shift from the } \\
\text { Younger Dryas-Holocene. }\end{array}$} & Arz et al. (1998) \\
\hline
\end{tabular}


Table 2

Details of drill sites and water depths for core locations of Ocean Drilling Program Legs 154 and 155.

\begin{tabular}{llrrrl}
\hline Site & Location & Latitude & Longitude & $\begin{array}{l}\text { Water depth } \\
(\mathrm{m})\end{array}$ & $\begin{array}{l}\text { Holes } \\
\text { drilled }\end{array}$ \\
\hline 925 & Ceara Rise & $4^{\circ} 12.2^{\prime} \mathrm{N}$ & $43^{\circ} 29.3^{\prime} \mathrm{W}$ & 3040 & 5 \\
926 & Ceara Rise & $3^{\circ} 431^{\prime} \mathrm{N}$ & $42^{\circ} 54.5^{\prime} \mathrm{W}$ & 3598 & 3 \\
927 & Ceara Rise & $5^{\circ} 27.7^{\prime} \mathrm{N}$ & $44^{\circ} 28.8^{\prime} \mathrm{W}$ & 3326 & 3 \\
930 & Upper Middle Amazon Fan & $5^{\circ} 0.9^{\prime} \mathrm{N}$ & $47^{\circ} 35.7^{\prime} \mathrm{W}$ & 3155 & 4 \\
931 & East Middle Amazon Fan & $5^{\circ} 8.5^{\prime} \mathrm{N}$ & $46^{\circ} 37.9^{\prime} \mathrm{W}$ & 3476 & 3 \\
932 & East Middle Amazon Fan & $5^{\circ} 12.7^{\prime} \mathrm{N}$ & $47^{\circ} 1.8^{\prime} \mathrm{W}$ & 3344 & 2 \\
933 & East Middle Amazon Fan & $5^{\circ} 5.8^{\prime} \mathrm{N}$ & $46^{\circ} 48.7^{\prime} \mathrm{W}$ & 3376 & 1 \\
934 & Amazon Fan Channel Fill & $5^{\circ} 29.0^{\prime} \mathrm{N}$ & $47^{\circ} 40.8^{\prime} \mathrm{W}$ & 3421 & 2 \\
935 & Middle Amazon Fan & $5^{\circ} 25.6^{\prime} \mathrm{N}$ & $47^{\circ} 33.9^{\prime} \mathrm{W}$ & 3486 & 1 \\
936 & Middle Amazon Fan & $5^{\circ} 37.9^{\prime} \mathrm{N}$ & $47^{\circ} 44.1^{\prime} \mathrm{W}$ & 3575 & 1 \\
937 & Central Upper Amazon Fan & $4^{\circ} 35.8^{\prime} \mathrm{N}$ & $47^{\circ} 12.4^{\prime} \mathrm{W}$ & 2951 & 4 \\
938 & Central Upper Amazon Fan & $4^{\circ} 39.5^{\prime} \mathrm{N}$ & $47^{\circ} 18.7^{\prime} \mathrm{W}$ & 2804 & 2 \\
939 & Central Upper Amazon Fan & $4^{\circ} 43.3^{\prime} \mathrm{N}$ & $47^{\circ} 30.2^{\prime} \mathrm{W}$ & 2784 & 3 \\
940 & Upper Middle Amazon Fan & $5^{\circ} 8.6^{\prime} \mathrm{N}$ & $47^{\circ} 31.7^{\prime} \mathrm{W}$ & 3191 & 1 \\
942 & Off Amazon Fan & $5^{\circ} 44.6^{\prime} \mathrm{N}$ & $49^{\circ} 5.5^{\prime} \mathrm{W}$ & 3346 & 3 \\
\hline
\end{tabular}

foraminiferal, isotopic and biostratigraphic, palaeomagnetic records, accelerator mass spectrometry (AMS) ${ }^{14} \mathrm{C}$ radiocarbon dating and orbital tuning (Bickert et al., 1997; Maslin et al., 1997; Mikkelsen et al., 1997; Showers et al., 1997). The position of the early Holocene was defined by the location of the Ericson Z/Y Zone boundary, based on the biostratigraphic foraminiferal framework of Ericson and Wollin (Ericson, 1961; Ericson and Wollin, 1968). Marked by the reappearance of the planktonic foraminifer Globorotalia tumida, this boundary has been independently dated using AMS ${ }^{14} \mathrm{C}$ dating and is coeval with the Holocene/Pleistocene boundary (Mikkelsen et al., 1997). The age tie-points for the Younger Dryas and Late Glacial were established on the basis of isotope stratigraphy (for MIS 2.1 and MIS 2.2, respectively) whilst the position of MIS 3 is marked by the Lake Mungo palaeomagnetic excursion which is present in 11 of the 15 sediment cores (Mikkelsen et al., 1997; Showers et al., 1997). In order to ensure the greatest possible degree of accuracy, the chronologies were compared to all other available records from the same sites (e.g. Maslin et al., 1997; Mikkelsen et al., 1997) using biostratigraphic and palaeomagnetic marker horizons.

A separate age model for the Ceara Rise was developed by orbitally tuning the magnetic susceptibility record from ODP Site 926 and the reliability of the magnetic susceptibility data was then cross-checked against a reference chronology (ODP Site 677, Panama Basin) (Bickert et al., 1997). Where it was not possible to ascertain an exact core depth for the relevant time-slice based on the presence of the relevant age tie-points, sample depths were calculated by the extrapolation of sedimentation rates from the published age-depth models.

\subsection{Core sampling}

Core sampling was undertaken at the IODP Core Repository, Universität Bremen. Prior to sampling, composite depth measurements determined above were converted to core section depths. $20 \mathrm{~cm}^{3}$ of sediment was sampled from sites on the Ceara Rise whilst $40 \mathrm{~cm}^{3}$ of sediment was taken from cores on the Amazon Fan due to reduced microfossil abundances. Care was taken during sampling to avoid sediments that had been visibly disturbed or affected by turbidites and samples were only taken from non-disturbed hemipelagic sediments. The high glacial sedimentation rates of the Amazon Fan negate any additional bioturbational effects. Samples were washed with distilled water over a $150 \mu \mathrm{m}$ mesh sieve and air-dried at $40{ }^{\circ} \mathrm{C}$. Material greater than $150 \mu \mathrm{m}$ was stored in clean glass vials for analysis. We note that, in places, the period of time represented by this sample size may vary depending on levee system development and core location. The dynamic nature of the Amazon Fan, characterised by extensive slumping and faulting, means that different parts of the Fan system are active at different times. This is reflected in complex variations in the sedimentation rates of different ODP Sites (Mikkelsen et al., 1997). We have tried to avoid complications caused by the complex nature of sediment deposition on the Amazon Fan by sampling at intervals with fixed age tie-points.

\subsection{Isotope measurements}

The coarse fraction $(>150 \mu \mathrm{m})$ was dry-sieved at discrete intervals and up to 30 individual planktonic foraminifera specimens of Globigerinoides ruber (white) (180-250 $\mu \mathrm{m})$; Globigerinoides sacculifer (315-350 $\mu \mathrm{m})$; Neogloboquadrina dutertrei (315-350 $\mu \mathrm{m})$ and Globorotalia truncatulinoides $(315-350 \mu \mathrm{m})$ were picked for analysis from the given size fraction. For samples of $G$. sacculifer, both non-sac (Globigerinoides trilobus trilobus) and sac-like (Globigerinoides trilobus sacculifer) forms were analysed depending on the abundance of each variant within a given sample. Studies have found the two variants to exhibit no significant difference in isotopic composition (Hecht, 1974). The four different species were selected in order to investigate glacial-interglacial changes in water column stratification. G. ruber and $G$. sacculifer are surface dwelling species with a calcification depth believed to be restricted to the upper $30 \mathrm{~m}$ of the water column whilst $N$. dutertrei calcifies within the mixed layer between depths of approximately $50-70 \mathrm{~m}$. G. truncatulinoides is a thermocline-dwelling species whose calcification depth is affected by the stratification of the water column (Sadekov et al., 2009). Isotope measurements were made at the University of Massachusetts using a Finnigan Kiel-III automated carbonate preparation system coupled with a Finnigan Delta + isotope ratio mass spectrometer. Values are expressed in $\delta$ (delta) per mil notation relative to Vienna PeeDee Belemnite (V-PDB) through calibration of an in house standard to the NBS-19 and NBS-18 standards. Long-term reproducibility of the standard is $\pm 0.1 \%$ 。 for oxygen.

\subsection{Sea surface temperatures}

The incorporation of the divalent cation $\mathrm{Mg}^{2+}$ into biogenic foraminiferal calcite is influenced by the temperature of ambient seawater. Because calcification temperatures are derived from the same medium as $\delta^{18} \mathrm{O}$ measurements it is possible to adjust for the temperature dependency of ${ }^{18} \mathrm{O} /{ }^{16} \mathrm{O}$ using $\mathrm{Mg} / \mathrm{Ca}$ ratios (Barker et al., 2005). Increasing $\mathrm{Mg} / \mathrm{Ca}$ ratios reflect increasing temperatures however ratios can be biased by the presence of clays, detrital grains, secondary carbonates and other contaminant phases (Barker et al., 2003). The use of $\mathrm{Mg} / \mathrm{Ca}$ thermometry is complicated by the postdepositional effects of dissolution which cause a lowering of $\mathrm{Mg} / \mathrm{Ca}$ ratios thought to represent the preferential removal of calcite formed at warmer temperatures (Dekens et al., 2002). G. ruber is thought to be the most accurate recorder of sea surface temperatures (SST) as a result of its restricted migration through the water column (Dekens et al., 2002; Lea et al., 2000). Dissolution in the area is found to be low in comparison to other tropical Atlantic sites (Curry and Cullen, 1997) and as all sites lie above the lysocline (4000-4300 m), it is thought that the effects of dissolution are limited. This is supported by the high abundance of $G$. ruber which, given a high susceptibility to dissolution (Berger, 1970), is thought to provide evidence that partial dissolution effects were minimal (Hastings et al., 1998).

Where microfossil abundances allowed, approximately 30 individual specimens of G. ruber (white) (250-315 $\mu \mathrm{m}$ ) were picked from 40 samples. Where necessary, other size fractions were incorporated to the sample in order to obtain a sample weight of $\sim 300 \mu \mathrm{g}$. The calcification depth of $G$. ruber is thought to be restricted to surface waters and thus the incorporation of different size fractions and comparison with $\delta^{18} \mathrm{O}$ data from smaller specimens are assumed to have a negligible effect. Samples were extensively cleaned using the method outlined by Barker et al. (2003) with the incorporation of an 
additional reductive cleaning step to ensure specimens were free from Fe-Mn coatings. Samples were analysed on a Vista Varian inductivelycoupled plasma optical emission spectrometer (ICP-OES) at the University of Cambridge. $\mathrm{Mg} / \mathrm{Ca}$ ratios were converted to SST estimates using a calibration equation developed using G. ruber in the Ceara Rise region and which contains a core depth-correction term for dissolution effects (Dekens et al., 2002):

$\mathrm{Mg} / \mathrm{Ca}=0.38 \exp 0.09$ [SST-0.61(core depth $\mathrm{km})]$

The depth correction is essentially a measure of how depth biases the SST estimate of sedimentary specimens and is only applied where core depth is greater than $2.8 \mathrm{~km}$ (all locations in this study except ODP Site 939). Due to the high degree of spatial variability observed in the data, we have set a conservative error of $5 \%$ for cleaning reproducibility in addition to the errors calculated for the intensity ratios and an application of a mean offset of 0.32 (calculated for samples exhibiting high levels of calcium) to the measured concentration ratios $(0.3 \% \mathrm{RSD}$ and $1 \% \mathrm{RSD}$ respectively). In addition, a standard error estimate of $\pm 1.2{ }^{\circ} \mathrm{C}$ is attached to the $\mathrm{Mg} / \mathrm{Ca}-\mathrm{SST}$ calibration equation where $95 \%$ confidence intervals for the preexponential and exponential constants are \pm 0.05 and \pm 0.015 respectively (Dekens et al., 2002). Despite this, the errors associated with the temperature estimates are still smaller than those attached to many other methods employed for temperature estimation, such as SIMMAX (Pflaumann et al., 1996).

\subsection{Palaeosalinity estimation}

Estimating changes in sea-surface salinity can provide useful information on changes in the local evaporation-precipitation budget and sea-surface hydrology due to variations in freshwater riverine input (Schmidt et al., 2004). Epstein and Mayeda (1953) found there is a linear relationship between salinity and the $\delta^{18} \mathrm{O}$ ratio of ocean water $\left(\delta^{18}{ }_{\mathrm{w}}\right)$. Weldeab et al. (2006) propose a linear regressional relationship for modern $\delta^{18}{ }_{\mathrm{w}}$-salinity whereby they demonstrate that salinity increases linearly with changes in ice-volume corrected $\delta^{18}{ }_{\mathrm{w}}$. Using temperature values derived from $\mathrm{Mg} / \mathrm{Ca}$ thermometry, variations in $\delta^{18}{ }_{w}$ were calculated using the palaeotemperature equation of Thunnell et al. (1999) that has been field-calibrated for use with $G$. ruber:

$\mathrm{T}=14.9-4.8\left(\delta_{\text {calcite }}-\left(\delta_{\mathrm{w}}^{18}-0.27\right)\right)$.

In instances where no SST measurement was obtained for a particular timeslice at a site, the average of the calculated SST values for that time was applied. In this instance, the Amazon Fan and Ceara Rise were treated separately. The ice-volume effect on $\delta^{18}{ }_{w}$ was calculated using a linear conversion from relative sea-level of $0.012 \% / \mathrm{m}$ sea-level fall (Shackleton, 1987) assuming that the sequestration of $\delta^{16} \mathrm{O}$ by continental ice sheets was linear through time.

\section{Results}

The methodologies adopted for this study provide a unique approach for assessing spatial variability in ocean dynamics over time. Using timeslice analysis at a variety of sites enables the spatial reconstruction of directional changes in the Amazon freshwater plume forced by hydrographic changes, in addition to the subsequent effect on oceanic temperature and salinity conditions. By placing less emphasis on downcore analysis of single sites, it is possible to better review surface current variations.

\subsection{Sea surface temperatures}

Reconstructed SSTs for the core-top samples (Fig. 2) give average values of $28.8 \pm 1.6{ }^{\circ} \mathrm{C}$ for the Amazon Fan and $28.9 \pm 1.3^{\circ} \mathrm{C}$ for the Ceara Rise, which are within the range of modern recorded data for the region which vary seasonally between 27.0 and $29.0^{\circ} \mathrm{C}$ (Levitus and Boyer, 1994). The spatial SST patterns are similar to those suggested by modern data with warmer waters radiating sea-ward from the mouth of the Amazon River such that sites on the upper part of the Amazon Fan (ODP 932 and 938) exhibit the highest SST values, and sites on the Ceara Rise (ODP Sites 925, 926, and 927) the lowest. However, SST values can vary by $>3{ }^{\circ} \mathrm{C}$ over a short distance, especially in the Modern and Early Holocene timeslices (Fig. 2). The results indicate an apparent glacial cooling of $3.2^{\circ} \mathrm{C}$ during the Late Glacial. This is consistent with values suggested by similar published studies for the area (Table 1 ). The results suggest a mean temperature increase across the study area from MIS 3 to the present day of $2.7 \pm 1.0^{\circ} \mathrm{C}$ and that the Younger Dryas was $2.2 \pm 0.7^{\circ} \mathrm{C}$ cooler than present.

\subsection{Freshwater outflow}

The quality of palaeosalinity estimations depends heavily on the reliability of the method used to calculate SST values. Uncertainties associated with SST calculations have the potential to dramatically reduce the precision of sea-surface salinity (SSS) measurements as large deviations are yielded from the propagation of errors (Rohling, 2000). This is particularly pronounced in the tropics where the slope of the $\delta^{18}{ }_{w}$-salinity relationship is shallow (Wolff et al., 1999). Due to the errors associated with the $\mathrm{Mg} / \mathrm{Ca}$ thermometry analysis, we use values of $\delta^{18}{ }_{w}$ (expressed in \% relative to $\mathrm{V}$-PDB) to reconstruct patterns of freshwater discharge over the Amazon Fan. $\delta{ }^{18}{ }_{\mathrm{w}}$ covaries linearly with salinity, and is estimated by subtracting the temperature component from values of $\delta^{18} \mathrm{O}_{\text {calcite. }}$

Karr and Showers (2002) suggest that there is a linear mixing relationship between freshwater and saline water, and that modification of this relationship by atmospheric processes is negligible. By adopting their simple two end-member mixing model, we assume that less positive values are indicative of a greater level of freshwater input from the Amazon River, and that changes in the spatial pattern of the results may be interpreted as shifts in the position of the river plume over time. We assume that the salinity (and thus the isotopic value) of the freshwater component will remain constant such that spatial changes in reconstructed $\delta^{18}{ }_{w}$ values reflect the relative balance of river:ocean water.

Modern salinity data obtained from satellite or shipboard measurements indicate the flow direction of river runoff as it is advected northwestwards by the NBC. Reconstructed $\delta^{18}$ w values from core-top samples and from the Early Holocene timeslice demonstrate a similar surface current such that the freshwater plume flows northwestwards with the NBC. During the colder stages (YD, Late Glacial, MIS3), lower values of $\delta^{18}{ }_{w}$ occur in the central Amazon Fan and Ceara Rise sites, implying a shift in the outflow direction of the freshwater plume. When computed for a comparison of quantifiable change between timeslices, values of $\delta^{18}{ }_{w}$ show an average decrease between the modern day and the Late Glacial, becoming lighter and hence fresher (Fig. 3 ).

\subsection{Stratification}

The difference in oxygen isotope composition $\left(\Delta \delta^{18} \mathrm{O}\right)$ between shallow (G. sacculifer) and thermocline-dwelling (G. truncatulinoides) species has been used as a proxy for water column stratification that is independent of ice volume and acts as a function of vertical mixing (Fig. 4). High values of $\Delta \delta^{18} \mathrm{O}$ represent large thermal gradients in sub-surface waters, indicative of increased stratification (Vink et al., 2002). The calcification depth of G. truncatulinoides is affected by 

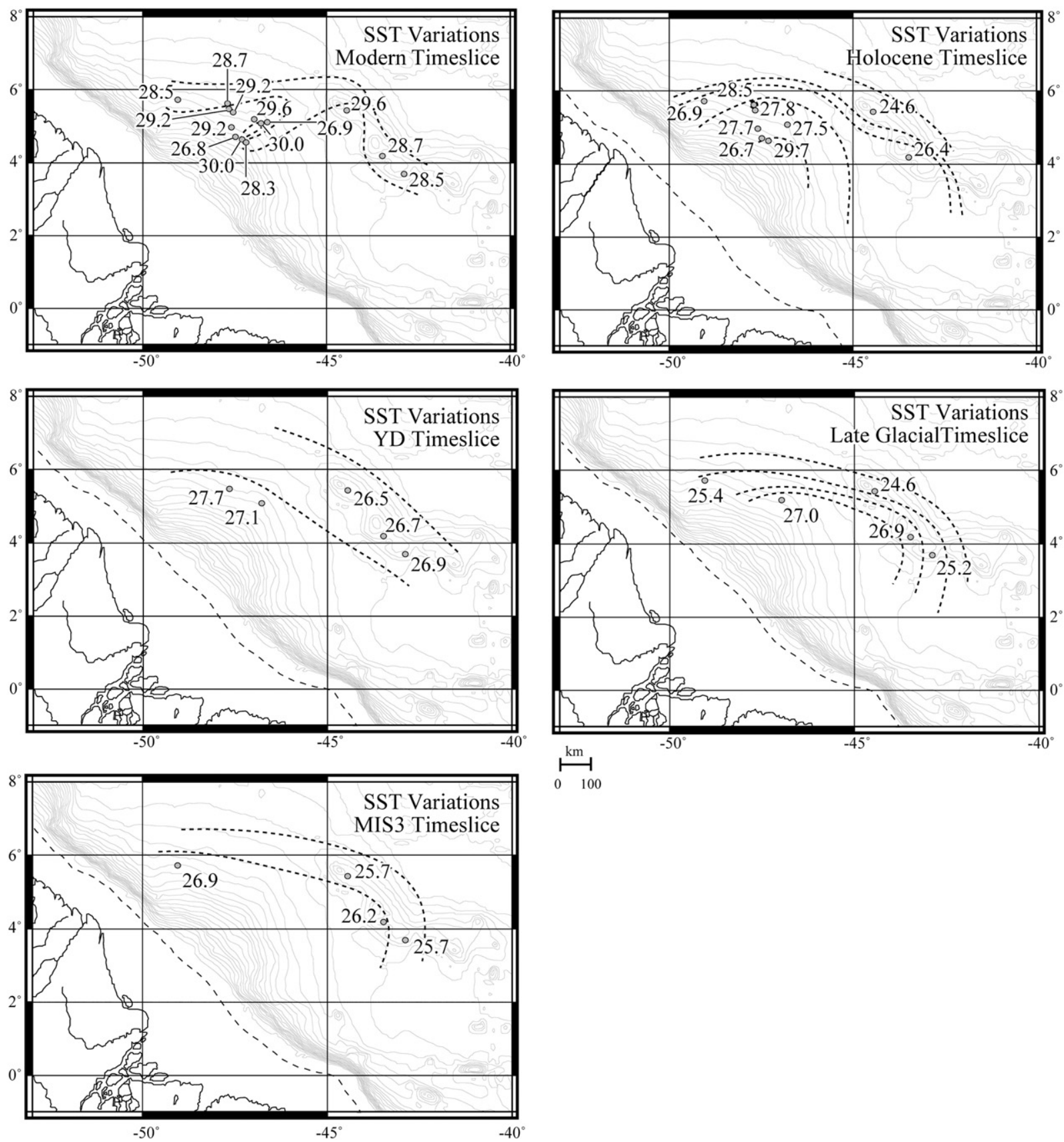

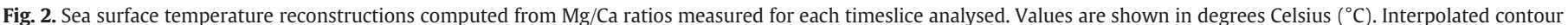
lines are plotted on the basis of visual interpretation.

water column stratification, and it is found exclusively below the mixed layer (Dürkoop et al., 1997).

In the core-top sediment samples from all sites in the study area, there was a markedly lower abundance of $G$. truncatulinoides in comparison to the older timeslices which is characteristic of intense water column stratification observed in the modern tropical Atlantic Ocean (Dürkoop et al., 1997). Values of $\Delta \delta^{18} \mathrm{O}$ reach a maximum in the tropics in relation to the contrast between the temperature conditions of deeper water masses and surface waters (Mulitza et al., 1997).

Averaged across all sites, values of $\Delta \delta^{18} \mathrm{O}$ increase consistently by $\sim 1 \%$ from MIS3 to the present day representing an increase in water column stratification. Mulitza et al. (1997) interpret an increase in $\Delta \delta^{18} \mathrm{O}$ of $\sim 1.2 \%$ from the Last Glacial Maximum to the Late Holocene as being indicative of a significant increase in water column stratification. This is comparable with the mean reduction observed across the Amazon Fan and Ceara Rise of $\sim 1 \%$, and is thought to be related to an increase in vertical mixing of the water column caused by higher surface water densities resulting from cooler, more saline glacial water conditions. Anomalously low values of $\delta^{18} \mathrm{O}(\mathrm{G}$. truncatulinoides) are recorded for the colder timeslices (YD, Late Glacial, and MIS3) at Site 927 (Fig. 4). This is in contrast to the pattern observed at other core sites and implies a marked increase in vertical mixing during these stages. However, these results are not supported by values at any other site and therefore are potentially indicative of regional differences in the hydrographic regime.

\section{Discussion}

\subsection{A cooler, less stratified glacial ocean}

Attention has increasingly focused on quantifying the degree of climate amelioration since the last glacial, and the results from a wide 


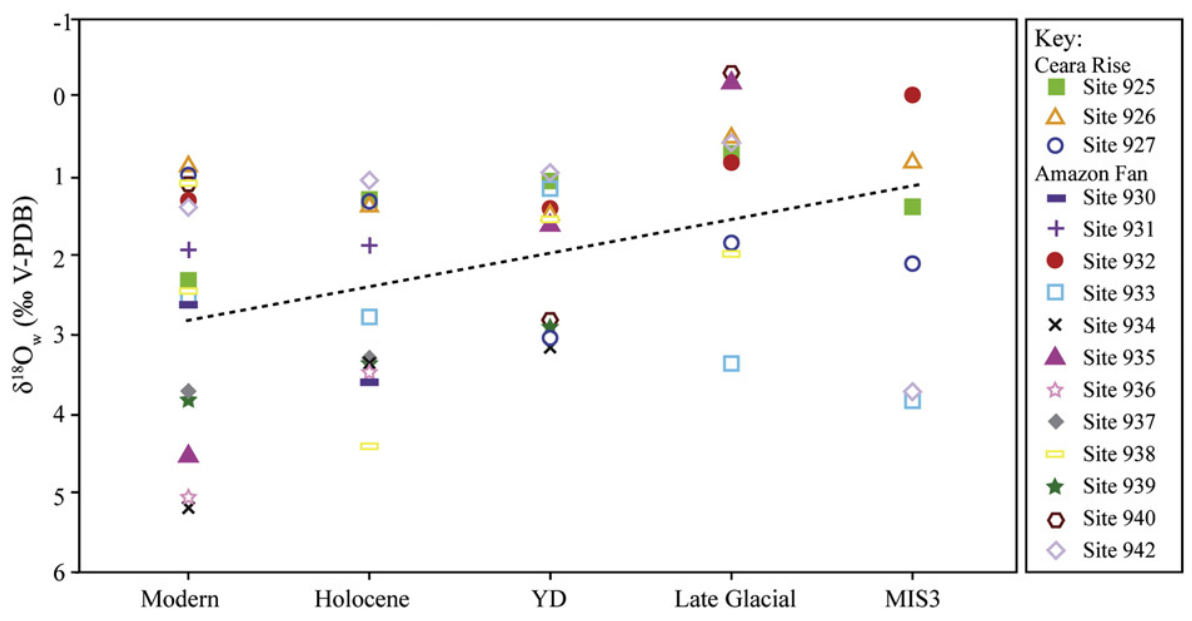

Fig. 3. Values of $\delta^{18} \mathrm{O}_{\text {local }}$ calculated from ice volume-corrected $\delta^{18}{ }_{\mathrm{w}}$ for each timeslice, depicted by site.

range of studies imply significant changes between the properties of the glacial and interglacial ocean. Our results suggest a mean increase in SST since the Late Glacial of $3.2 \pm 1.1^{\circ} \mathrm{C}$ which is comparable to the findings of similar studies in the western equatorial Atlantic (Table 1). Both the smallest and largest temperature offsets between the Late Glacial and present day are observed on the Ceara Rise, at Site 925 $\left(1.8 \pm 1.2^{\circ} \mathrm{C}\right)$, and at Site $927\left(5.0 \pm 1.2^{\circ} \mathrm{C}\right)$ respectively. The temperature offsets at other sites are consistent with the degree of mean estimated cooling. This difference is possibly reflective of the implied southward shift in the Amazon freshwater plume during the Late Glacial, delivering warmer water to Sites 927 and 925 during the Modern and Late Glacial respectively. The results also indicate a mean warming since MIS3 of $2.7 \pm 1.0^{\circ} \mathrm{C}$; since the Younger Dryas of $2.2 \pm 0.7^{\circ} \mathrm{C}$ and since the Early Holocene of $1.7 \pm 1.2^{\circ} \mathrm{C}$. The results suggest that MIS3 was significantly cooler than present, in accordance with the ongoing glacial conditions suggested by Dürkoop et al. (1997). The resulting temperature shifts since the Younger Dryas and Early Holocene are lower in magnitude than those outlined in Table 2; however the paucity of temperature proxy records for these periods complicates any attempt to make an adequate comparison.

Our suggested average temperature increase of $3.2^{\circ} \mathrm{C}$ since the Late Glacial is consistent with results from other palaeotemperature reconstructions in the Southern Ocean $\left(2.2 \pm 0.4{ }^{\circ} \mathrm{C}\right.$, Smart et al., 2010), Pacific Ocean $\left(3^{\circ} \mathrm{C}\right.$, Lea et al., $2000 ; 3.5-4.0^{\circ} \mathrm{C}$, Visser et al., 2003), Atlantic Ocean $\left(5^{\circ} \mathrm{C}\right.$, Guilderson et al., $2001 ; 5-6{ }^{\circ} \mathrm{C}$, Gersonde et al., 2005) and the South China Sea ( $4^{\circ} \mathrm{C}$, Tian et al., 2010; $2-3^{\circ} \mathrm{C}$,
Wang et al., 2010). It is also in line with the $3.25 \pm 0.55^{\circ} \mathrm{C}$ temperature decrease estimated from the LR04 global stack (Clark et al., 2009).

The extensive spatial variation in plotted values of $\delta^{18}{ }_{w}$ suggests that different locations are responding to complex and highly localised changes in salinity driven by the influence and proximity of the freshwater plume. An increase in the salinity of the glacial ocean has been demonstrated in a number of studies (e.g. Dürkoop et al., 1997; Schmidt et al., 2004; Weldeab et al., 2006).

Differences in the $\delta^{18} \mathrm{O}$ values of G. sacculifer and G. truncatulinoides reflect the degree of stratification of the upper water column. Results are comparable with modern observations that the ocean is well stratified (e.g. Dürkoop et al., 1997; Mulitza et al., 1997; Vink et al., 2002). The results indicate an overall increase in the degree of vertical mixing of the water column, however variation between sites restricts the interpretation of overall change as some sites record only a relatively minor decrease $\left(\sim 0.4 \%\right.$ o in $\Delta \delta^{18}$ O between the modern and Late Glacial timeslices. The observed decrease in stratification may result from an increased proximity to the river mouth due to sea level regression creating turbulent mixing conditions and water column instability at the edge of the continental shelf. The record for Site 927 shows a particularly marked decrease in $\Delta \delta^{18} \mathrm{O}$ during the YD, Late Glacial and MIS3 timeslices. The suggested lack of upper-ocean stratification may also be a result of the proximity of this site to the flowpath of the NECC or related to the shift of freshwater outflow resulting in cooler sea-surface temperatures precluding the formation of an overlying freshwater barrier layer enhancing stratification. Vink

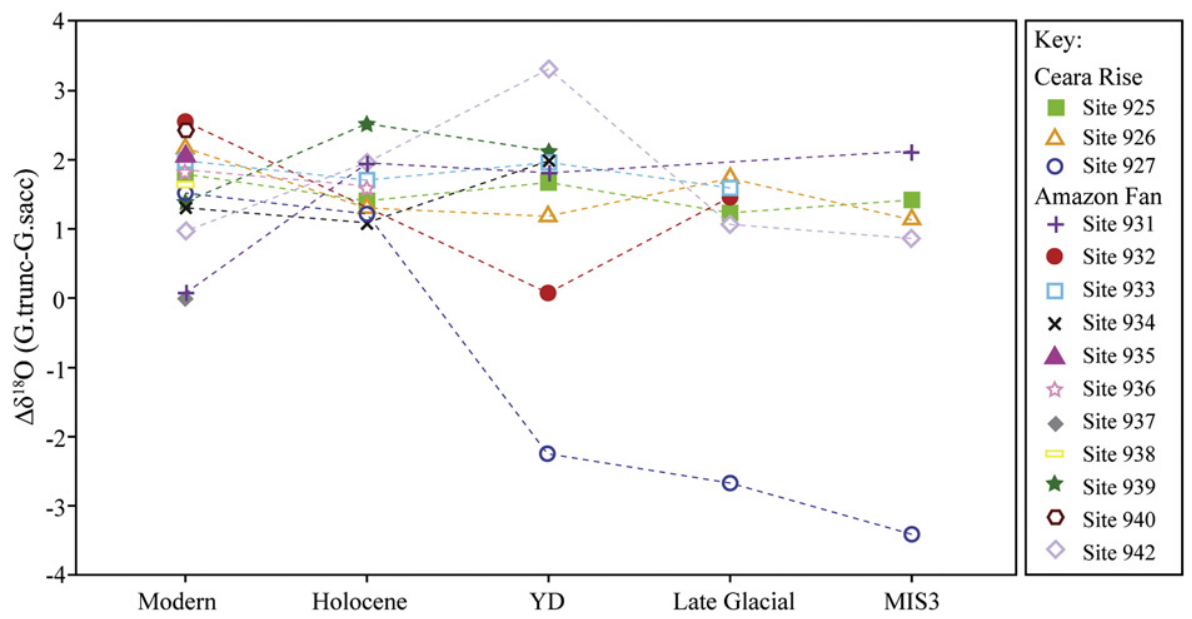

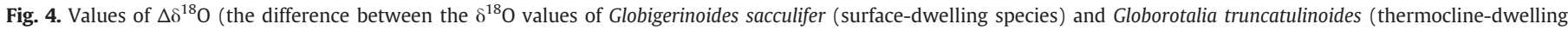

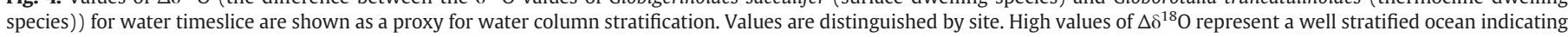
that mean ocean stratification in the study area decreased during glacial stages. 
et al. (2002) suggest that active downwelling along the boundary of the NECC, synchronous with a deepening of the thermocline, may explain increased vertical mixing in the water column. This is also inferred from low abundances of Florisphaera profunda, a lower photic zone coccolithophore associated with a deep nutricline. As the thermocline and nutricline depths vary concurrently, it is found that the abundance of $F$. profunda provides a reliable indicator of fluctuations in thermocline depth at the Ceara Rise (Kameo et al., 2004; Mertens et al., 2009).

ODP Site 927 on the northern edge of the Ceara Rise is typical of the changes observed across the region. Core-top samples indicate that oceanic conditions at this site are characterised by warm, stratified waters resulting from its proximity to the modern flowpath of the NECC. In contrast, during glacial stages, the area is characterised by colder, well-mixed waters. The results suggest a cooler, less stratified glacial ocean that is influenced by directional changes in the outflow of the Amazon freshwater plume during the YD and Late Glacial.

\subsection{Prolonged retroflection of the $N B C$}

Whilst the Amazon River modifies local ocean dynamics and affects the salinity patterns, the dispersal of freshwater is primarily controlled by ocean circulation and therefore it is likely that changes in surface currents are the principal driving mechanism behind the glacial-interglacial spatial variations. Modern seasonal changes in the NECC are related to the migration of the ITCZ such that NECC formation and NBC retroflection are strongest during boreal summer and autumn when the ITCZ is in its northernmost position (Johns et al., 1998). At the same time, surface flow is reinforced by southeasterly winds which enhance a seasonal deepening of the thermocline (Bassinot et al., 1997; Bourles et al., 1999).

The inferred oceanward spread of freshwater during the Late Glacial and YD differs from the present day scenario where warm, fresh river water is advected in a northwesterly direction along the continental shelf (Fig. 5). The proposed patterns of plume dispersal for the YD, Late Glacial and MIS3 show a southward displacement of the freshwater outflow in comparison to the present, implying a reduction in the volume of fresh water transported northwards by the NBC. Maslin et al. (1997) speculated that periodic increases in the latitudinal thermal gradient may have led to the curtailment of crossequatorial transport of heat and salinity by the NBC, and postulate a prolonged or even continual NBC retroflection. Rühlemann et al. (2001) propose that conditions analogous to the modern boreal summer persisted during glacial stages in the Late Quaternary, controlled by the development of a $\mathrm{W}$-E pressure gradient driven by intensified SE trade winds which result in a strengthening of the NECC and a more vigorous eastward surface water flow increasing terrestrial sediment delivery to the Amazon Fan and Ceara Rise. This is consistent with the results of this study which imply a south and eastward deflection of the Amazon freshwater plume (Fig. 5).

Strengthening of the NBC retroflection is associated with changes in mixed layer and thermocline depth which deepen as a result of an increased $\mathrm{W}$-E pressure gradient. Evidence for a deeper thermocline is suggested by a decrease in $\Delta \delta^{18} O$ values (Fig. 4) during glacial stages, which combined with the shift in the freshwater plume, implied by spatial variations in $\delta^{18}{ }_{\mathrm{w}}$ and may be interpreted as a prolongation of the NBC retroflection in colder climates. A resulting decrease in cross-equatorial transport of heat and salinity by the NBC to the Guyana Current has implications for the strength of the glacial Gulf Stream and hence for the production of NADW and global thermohaline circulation. The hypothesised increase in glacial salinity extends across the tropics from the western equatorial Atlantic to the Caribbean Sea (Schmidt et al., 2004). The tropical accumulation of salt and warmth that would result from a reduction in northward NBC transport ultimately impacts upon the density of high latitude surface waters and thus has important implications for the formation and production of NADW. A glacial slowdown in thermohaline circulation is believed to have been a key component in propagating and maintaining glacial climate conditions (Clark et al., 2002). NADW production is thought to have ceased, or have been strongly reduced during glacial episodes, as a result of increased meltwater influx in the northern hemisphere (Rahmstorf, 2002) and a reduction in NADW production may have led to an increased northward penetration of the Antarctic Bottom Water (AABW) during glacial stages. This theory is supported by studies of the benthic $\delta^{13} \mathrm{C}$ record preserved in Ceara Rise sediments which suggest a shift in deep oceanic water mass properties, concurrent with a dominant influence of the AABW (Bickert et al., 1997).

Circulation in the western equatorial Atlantic and modern day variations in the NBC are driven by seasonal variations in the strength of NE and SE trade winds. Driven by intensified SE trade winds, crossequatorial transport by the NBC is controlled by the northward migration of the ITCZ into the northern hemisphere (Rühlemann et al., 2001). The position of the ITCZ is strongly coupled with variations in the latitudinal temperature gradient such that, during glacial stages, an increased thermal gradient between the north and tropical Atlantic Ocean would have resulted in an intensification of zonal wind patterns which, in turn, would impede the penetration of the ITCZ into the northern hemisphere, culminating in a mean southward shift in its position (Heil et al., 2006). The resulting hemispheric-wide adjustments in atmospheric circulation strongly modify surface currents in the western equatorial Atlantic, causing a curtailment of cross-equatorial transport and a strengthening of the NBC retroflection and the NECC. A more mean southerly position of the ITCZ during glacial stages has been suggested by a number of authors (e.g. Bassinot et al., 1997; Heil et al., 2006; Lea et al., 2003; Maslin et al., 1997; Peterson et al., 2000; Rühlemann et al., 2001; Wang et al., 2004) and would have important implications for changes in the precipitation regimes that presently characterise South American climate by inducing enhanced aridification in northern South America, as implied by records from the Cariaco Basin (Haug et al., 2001; Peterson et al., 2000) and increased precipitation and humidity further south (Wang et al., 2004). If the values of $\delta^{18}{ }_{w}$ are a true reflection of an increase in Amazon outflow, this implies an increase in precipitation over the Amazon Basin during the LGM.

\section{Conclusions}

The unique potential of the Amazon Fan to offer detailed, highresolution palaeoclimate records for the Late Quaternary is important for investigating the role of ocean circulation as a key component of climatic change. Oxygen isotope analyses and $\mathrm{Mg} / \mathrm{Ca}$ palaeothermometry performed on planktonic foraminifera sampled from sites on the Amazon Fan and Ceara Rise relate to spatial and temporal changes in the dispersal of the River Amazon freshwater plume. Analysis of these variations over the last 30,000 yr has shown that:

1. Changes in sea surface temperatures are highly spatially complex and can alter in response to fluctuations in the influence of warmer water sourced from the River Amazon. A suggested sea-surface cooling of $\sim 3.2 \pm 1.1{ }^{\circ} \mathrm{C}$ during the Late Glacial is consistent with observations made by previous studies. The ability of the techniques adopted to accurately reflect modern temperature conditions is hampered by uncertainty surrounding the degree of dissolution coupled with mechanical problems experienced during sample analysis. Due to complex changes in surface water circulation, the use of multiple site analysis is preferable to single site analyses.

2. A broad reduction in the stratification of the glacial ocean, observed in $\Delta \delta^{18} \mathrm{O}$ (G. truncatulinoides-G. sacculifer) values, indicates an increase in the degree of vertical mixing of the water column in colder climates characterised by a deepening of the thermocline. 

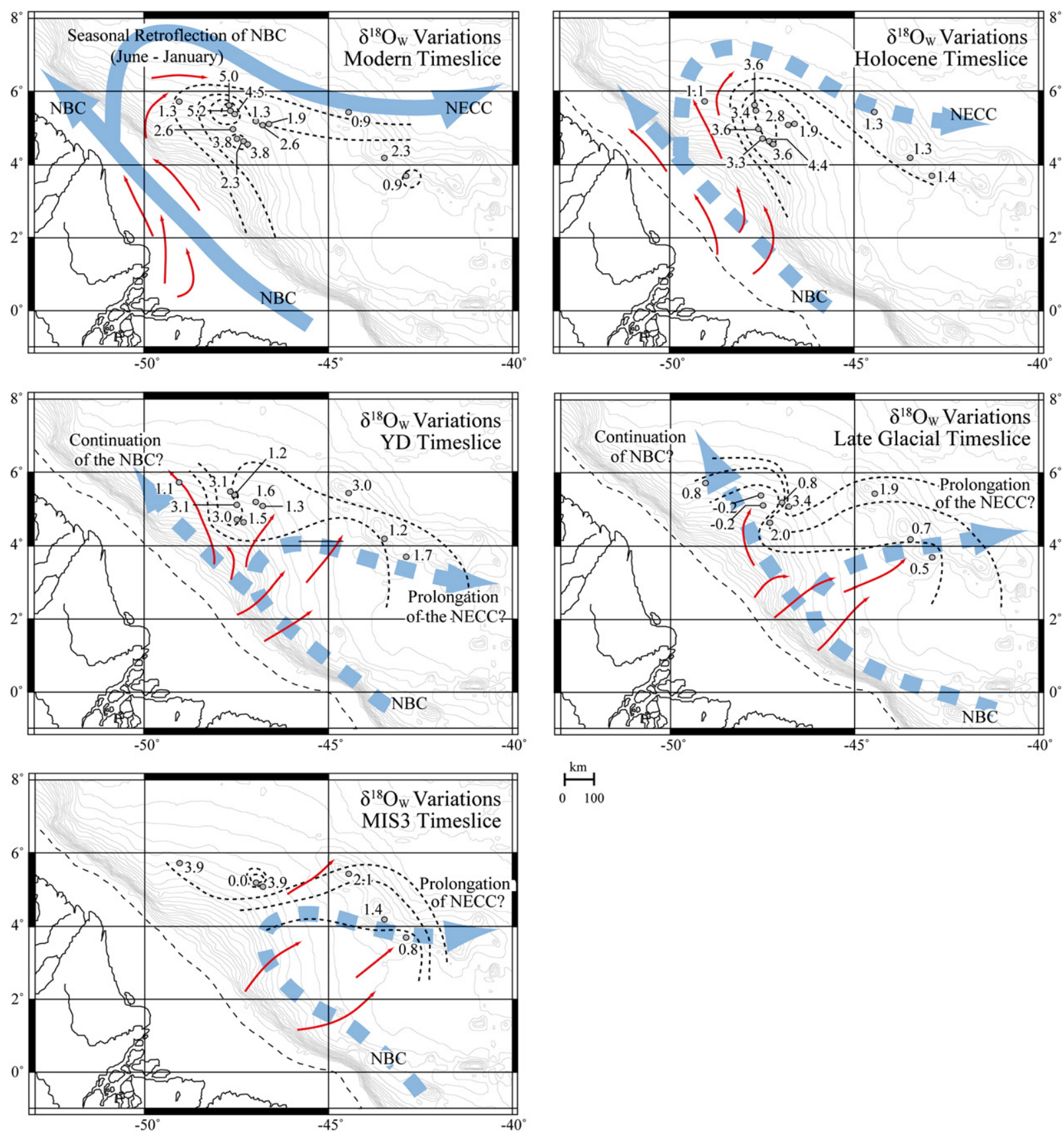

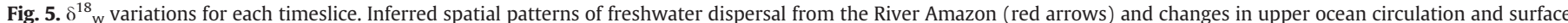

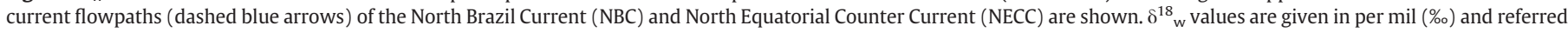
to V-PDB. Interpolated contour lines are plotted on the basis of visual interpretation.

3. Calculated values of $\delta^{18} \mathrm{O}_{\text {calcite }}$ and $\delta^{18}{ }_{\mathrm{w}}$ are subject to highly localised spatial variations, probably resulting from complexities surrounding the advection of the freshwater plume by upper-level ocean current and the detachment of low salinity lenses.

4. An oceanward deflection of the Amazon freshwater plume occurred during the Younger Dryas, the Late Glacial and MIS 3 colder stages, driven by a prolongation in the duration of the NBC retroflection and a strengthening of the NECC forced by intensified zonal trade winds which impeded the northward migration of the ITCZ.

\section{Acknowledgements}

We are grateful to H. Elderfield, A. Tripati and M. Greaves for help with $\mathrm{Mg} / \mathrm{Ca}$ analyses at Cambridge University. We also thank W. Hale for assistance with core sampling at IODP Repository, Bremen and J. Hope and T. Maxted for help with sample preparation. We are grateful to C. Hoorn and one anonymous reviewer for constructive comments which helped improve this manuscript. Requests for data and materials should be made to KEW. This work was supported by a Natural Environmental Research Council MSc studentship award to KEW (NER/S/M/2005/13573).

\section{References}

Arz, H.W., Pätzold, J., Wefer, G., 1998. Correlated millennial-scale changes in surface hydrography and terrigenous sediment yield inferred from last-glacial marine deposits off northeastern Brazil. Quaternary Research 50, 15-166.

Barker, S., Greaves, M., Elderfield, H., 2003. A study of cleaning procedures used for foraminiferal $\mathrm{Mg} / \mathrm{Ca}$ palaeothermometry. Geochemistry, Geophysics, Geosystems 4 doi:10.1029/2003GC000559. 
Barker, S., Cacho, I., Benway, H., Tachikawa, K., 2005. Planktonic foraminiferal $\mathrm{Mg} / \mathrm{Ca}$ as a proxy for past oceanic temperatures: a methodological overview and data compilation for the Last Glacial Maximum. Quaternary Science Reviews 24, 821-834.

Bassinot, F.C., Beaufort, L., Vincent, E., Labeyrie, L., 1997. Changes in the dynamics of western equatorial Atlantic surface currents and biogenic productivity at the midPleistocene revolution (930 ka). In: Shackleton, N.J., Curry, W.B., Richter, C., Bralower, T.J. (Eds.), Proceedings of the Ocean Drilling Program, Scientific Results, vol. 154. Ocean Drilling Program, College Station, TX, U.S.A, pp. 269-284.

Behling, H., Hooghiemstra, H., 1999. Environmental history of the Colombian savannas of the Llanos Orientales since the Last Glacial Maximum from lake records El Pinai and Carimagua. Journal of Paleolimnology 21, 461-476.

Behling, H., Arz, H.W., Pätzold, J., Wefer, G., 2002. Late Quaternary vegetational and climate dynamic in southeastern Brazil, inferences from marine cores GeoB 3229-2 and GeoB 3202-1. Palaeogeography, Palaeoclimatology, Palaeoecology 179, 227-243.

Berger, W.H., 1970. Planktonic foraminifera: selective solution and the lysocline Marine Geology 8, 111-138.

Berger, W.H., Wefer, G., 1996. Central themes of South Atlantic circulation. In: Wefer, G Berger, W.H., Siedler, G., Webb, D.J. (Eds.), The South Atlantic: Present and Past Circulation. Springer-Verlag, Heidelberg, Germany, pp. 1-11

Bickert, T., Curry, W.B., Wefer, G., 1997. Late Pliocene to Holocene (2.6-0 Ma) western equatorial Atlantic deep-water circulation: inferences from benthic stable isotopes. In: Shackleton, N.J., Curry, W.B., Richter, C., Bralower, T.J. (Eds.), Proceedings of the Ocean Drilling Program, Scientific Results, vol. 154. Ocean Drilling Program, College Station, TX, U.S.A, pp. 239-254.

Bond, G., Broecker, W.S., Johnsen, S., McManus, J., Labeyrie, L., Jouzel, J., Bonani, G., 1993. Correlations between climate records from North Atlantic sediments and Greenland ice. Nature 365, 143-147.

Bourles, B., Gouriou, Y., Chuchla, R., 1999. On the circulation and upper layer of the western equatorial Atlantic. Journal of Geophysical Research 104 (C9), 21151-21170.

Broecker, W.S., 1997. Mountain glaciers: recorders of atmospheric water vapour content? Global Biogeochemical Cycles 11, 589-597.

Bush, M.B., Miller, M.C., Oliveira, P.E.D., Colinvaux, P.A., 2002. Orbital-forcing signal in sediments of two Amazonian lakes. Journal of Paleolimnology 27, 341-352.

Clark, P.U., Pisias, N.G., Stocker, T.F., Weaver, A.J., 2002. The role of thermohaline circulation in abrupt climate change. Nature $415,863-869$.

Clark, P.U., Dyke, A.S., Shakun, J.D., et al., 2009. The last glacial maximum. Science 325 710-714.

CLIMAP Project Members, 1976. The surface of ice age Earth. Science 191, 1131-1137.

Colinvaux, P.A., De Oliveira, P.E., Moreno, J.E., Miller, M.C., Bush, M.B., 1996. A long pollen record from lowland Amazonia: forest and cooling in glacial times. Science 274, 85-88.

Curry, W.B., Cullen, J.L., 1997. Carbonate production and dissolution in the western equatorial Atlantic during the last 1 m.y. In: Shackleton, N.J., Curry, W.B., Richter, C. Bralower, T.J. (Eds.), Proceedings of the Ocean Drilling Program, Scientific Results, vol. 154. Ocean Drilling Program, College Station, TX, U.S.A., pp. 189-199.

Curry, W.B., Shackleton, N.J., Richter, C., et al., 1995. Proceedings of the Ocean Drilling Program, Initial Reports, vol. 154. Ocean Drilling Program, College Station, TX, U.S.A.

Curtis, J.H., Brenner, M., Hodell, D.A., 1999. Climate change in the Lake Valencia Basin, Venezuela, 12, 600 yr BP to present. Holocene 9, 609-619.

Dahl, K.A., Broccoli, A.J., Stouffer, R.J., 2005. Assessing the role of North Atlantic freshwater forcing in millennial scale climate variability: a tropical Atlantic perspective. Climate Dynamics 24, 325-346.

Damuth, J.E., Kumar, N., 1975. Amazon cone: morphology, sediments, age, and growth pattern. Geological Society of America Bulletin 86, 863-878

Dekens, P.S., Lea, D.W., Pak, D.K., Spero, H.J., 2002. Core top calibration of $\mathrm{Mg} / \mathrm{Ca}$ in tropical foraminifera: refining paleotemperature estimation. Geochemistry, Geophysics, Geosystems 3 doi:10.1029/2001GC000200.

Didden, N., Schott, F.A., 1993. Eddies in the North Brazil Current retroflection region observed by Geosat altimetry. Journal of Geophysical Research 98, 20121-20131.

Dürkoop, A., Hale, W., Mulitza, S., Pätzold, J., Wefer, G., 1997. Late Quaternary variations of sea surface salinity and temperature in the western tropical Atlantic: evidence from $\delta^{18} \mathrm{O}$ of Globigerinoides sacculifer. Paleoceanography 12, 764-772.

Epstein, S., Mayeda, T., 1953. Variation of 018 content of waters from natural sources. Geochimica et Cosmochimica Acta 4, 213-224

Ericson, D.B., 1961. Pleistocene climatic record in some deep-sea sediment cores Annals of the New York Academy of Sciences 95, 537-541.

Ericson, D.B., Wollin, G., 1968. Pleistocene climates and chronology in deep-sea sediments. Science 162, 1227-1234.

Ettwein V.E., 2004. South American palaeoclimate reconstruction. PhD thesis, University College London, London.

Figueiredo, J., Hoorn, C., van der Ven, P., Soares, E., 2009. Late Miocene onset of the Amazon River and the Amazon deep-sea fan: evidence from the Foz do Amazonas Basin. Geology 37, 619-622.

Figueiredo, J., Hoorn, C., van der Ven, P., Soares, E., 2010. Late Miocene onset of the Amazon River and the Amazon deep-sea fan: evidence from the Foz do Amazonas Basin: reply. Geology 38, e213 doi:10.1130/G31057Y.1.

Gersonde, R., Crosta, X., Abelmann, A., Armand, L., 2005. Sea-surface temperature and sea ice distribution of the Southern Ocean at the EPILOG Last Glacial Maximum-a circum-Antarctic view based on siliceous microfossil records. Quaternary Science Reviews 24, 869-896.

Gibbs, R.J., 1970. Circulation in the Amazon River Estuary and adjacent Atlantic Ocean. Journal of Marine Research 28, 113-123.

Guilderson, T.P., Fairbanks, R.G., Rubenstone, J.L., 1994. Tropical temperature variations since 20, 000 years ago: modulating interhemispheric climate change. Science 263 663-665.
Guilderson, T.P., Fairbanks, R.G., Rubenstone, J.L., 2001. Tropical Atlantic coral oxygen isotopes: glacial-interglacial sea surface temperatures and climate change. Marine Geology 172, 75-89.

Harris, S.E., Mix, A.C., King, T., 1997. Biogenic and terrigenous sedimentation at Ceara Rise, western tropical Atlantic, supports Pliocene-Pleistocene deep-water linkage between hemispheres. In: Shackleton, N.J., Curry, W.B., Richter, C., Bralower, T.J. (Eds.), Proceedings of the Ocean Drilling Program, Scientific Results, vol. 154. Ocean Drilling Program, College Station, TX, U.S.A., pp. 331-345.

Hastings, D.W., Russell, A.D., Emerson, S.R., 1998. Foraminiferal magnesium in Globigerinoides sacculifer as a paleotemperature proxy. Paleoceanography 13, 161-169.

Haug, G.H., Hughen, K.A., Sigman, D.M., Peterson, L.C., Röhl, U., 2001. Southward migration of the Intertropical Convergence Zone through the Holocene. Science 293, 1304-1308.

Hecht, A.D., 1974. Intraspecific variation in recent populations of Globigerinoides ruber and Globigerinoides trilobus and their application to paleoenvironmental analysis. Journal of Paleontology 48, 1217-1234.

Heil, G.M.N., Arz, H.W., Behling, H., Wefer, G., 2006. Extent of high northern latitude forcing on tropical/subtropical South American precipitation during the last glacial. Geophysical Research Abstracts 8 (07138).

Hoorn, C., Guerrero, J., Sarmiento, G.A., Lorente, M.A., 1995. Andean tectonics as a cause for changing drainage patterns in Miocene northern South America. Geology 23, 234-240.

Hüls, M., Zahn, R., 2000. Millennial-scale sea surface temperature variability in the western tropical North Atlantic from planktonic foraminiferal census counts. Paleoceanography 15, 659-678.

Johns, W.E., Lee, T.N., Beardsley, R.C., Candela, J., Limeburner, R., Castro, B., 1998. Annual cycle and variability of the North Brazil Current. Journal of Physical Oceanography $28,103-128$

Kameo, K., Shearer, M.C., Droxler, A.W., Mita, I., Watanabe, R., Sato, T., 2004. Glacialinterglacial surface water variations in the Caribbean Sea during the last $300 \mathrm{ky}$ based on calcareous nannofossil analysis. Palaeogeography, Palaeoclimatology, Palaeoecology 212, 65-76.

Karr, J.D., Showers, W.J., 2002. Stable oxygen and hydrogen isotopic tracers in Amazon shelf waters during AMASSEDS. Oceanological Acta 25, 71-78.

Lea, D.W., Pak, D.W., Spero, H.J., 2000. Climate impact of late quaternary equatorial Pacific sea surface temperature variations. Science 289, 1719-1724.

Lea, D.W., Pak, D.K., Peterson, L.C., Hughen, K.A., 2003. Synchroneity of tropical and high-latitude Atlantic temperatures over the Last Glacial termination. Science 301, 1361-1364.

Levitus, S., Boyer, T.P., 1994. World Ocean Atlas, Temperature, NOAA Atlas, NESDIS. National Ocean and Atmosphere Administration, Silver Spring, MD.

Liu, K.-B., Colinvaux, P.A., 1985. Forest changes in the Amazon Basin during the last glacial maximum. Nature 318, 556-557.

Maslin, M.A., Burns, S.J., 2000. Reconstruction of the Amazon Basin effective moisture availability over the past 14, 000 years. Science 290, 2285-2287.

Maslin, M.A., Burns, S.J., Erlenkeuser, H., Hohnemann, C., 1997. Stable isotope records from sites 932 and 933. In: Flood, R.D., Piper, D.J.W., Klaus, A., Peterson, L.C. (Eds.), Proceedings of the Ocean Drilling Program, Scientific Results, vol. 155. Ocean Drilling Program, College Station, TX, U.S.A., pp. 305-318.

Mertens, K.N.J.M., Lynn, M., Aycard, M., Ling, H.-L., Louwye, S., 2009. Coccolithophores as palaeoecological indicators for shifts of the ITCZ in the Cariaco Basin during the late Quaternary. Journal of Quaternary Science 24, 159-174.

Mikkelsen, N., Maslin, M.A., Giraudeau, J., Showers, W.J., 1997. Biostratigraphy and sedimentation rates of the Amazon Fan. In: Flood, R.D., Piper, D.J.W., Klaus, A., Peterson, L.C. (Eds.), Proceedings of the Ocean Drilling Program, Scientific Results, vol. 155. Ocean Drilling Program, College Station, TX, U.S.A., pp. 577-594.

Mix, A.C., Morey, A.E., Pisias, N.G., Hostetler, S.W., 1999. Foraminiferal faunal estimates of palaeotemperature: circumventing the no-analog problem yields cool ice age tropics. Paleoceanography 14, 350-359.

Mora, G., Pratt, L.M., 2001. Isotopic evidence for cooler and drier conditions in the tropical Andes during the last glacial stage. Geology 29, 519-522.

Mulitza, S., Dürkoop, A., Hale, W., Wefer, G., Niebler, H.S., 1997. Planktonic foraminifera as recorders of past surface-water stratification. Geology 25, 335-338.

Müller-Karger, F.E., McClain, C.R., Richardson, P.L., 1988. The dispersal of the Amazon's water. Nature 333, 56-59.

Peterson, L.C., Haug, G.H., Hughen, K.A., Röhl, U., 2000. Rapid changes in the hydrologic cycle of the tropical Atlantic during the last glacial. Science 290, 1947-1951.

Pflaumann, U., Duprat, J., Pujol, C., Labeyrie, L.D., 1996. SIMMAX: a modern analogue technique to deduce Atlantic sea surface temperatures from planktonic foraminifera in deep-sea sediments. Paleoceanography 11, 15-35.

Rahmstorf, S., 2002. Ocean circulation and climate during the past 120 , 000 years. Nature 419, 207-214

Rohling, E.J., 2000. Palaeosalinity: confidence limits and future applications. Marine Geology 163, 1-11.

Rühlemann, C., Mulitza, S., Müller, P.J., Wefer, G., Zahn, R., 1999. Warming of the tropical Atlantic Ocean and slowdown of thermohaline circulation during the last deglaciation. Nature 402, 511-514.

Rühlemann, C., Diekmann, B., Mulitza, S., Frank, M., 2001. Late Quaternary changes of western equatorial Atlantic surface circulation and Amazon lowland climate recorded in Ceara Rise deep-sea sediments. Paleoceanography 16, 293-305.

Sadekov, A., Eggins, S.M., De Deckker, P., Ninnemann, U., Kuhnt, W., Bassinot, F., 2009. Surface and subsurface seawater temperature reconstruction using $\mathrm{Mg} / \mathrm{Ca}$ microanalysis of planktonic foraminifera Globigerinoides ruber, Globigerinoides sacculifer, and Pulleniatina obliquiloculata. Paleoceanography 24, PA3201 doi:10.1029/2008PA001664. 
Schmidt, M.W., Spero, H.J., Lea, D.W., 2004. Links between salinity variation in the Caribbean and North Atlantic thermohaline circulation. Nature 428, 160-163.

Schrag, D.P., Hampt, G., Murray, D.W., 1996. Pore fluid constraints on the temperature and oxygen isotope composition of the glacial ocean. Science 272, 1930-1932.

Seltzer, G.O., Rodbell, D.T., Baker, P.A., Fritz, S.C., Tapia, P.M., Rowe, H.D., Dunbar, R.B., 2002. Early warming of tropical south America at the last glacial interglacial transition. Science 296, 1685-1686.

Shackleton, N.J., 1987. Oxygen isotopes, ice volume and sea-level. Quaternary Science Reviews 6, 183-190.

Showers, W.J., Schneider, R., Mikkelsen, N., Maslin, M.A., 1997. Isotopic stratigraphy of Amazon fan sediments. In: Flood, R.D., Piper, D.J.W., Klaus, A., Peterson, L.C. (Eds.), Proceedings of the Ocean Drilling Program, Scientific Results, vol. 155. Ocean Drilling Program, College Station, TX, U.S.A, pp. 281-304.

Smart, C.W., Waelbroeck, C., Michel, E., Mazaud, A., 2010. Benthic foraminiferal abundance and stable isotope changes in the Indian Ocean sector of the Southern Ocean during the last $20 \mathrm{kyr}$ : paleoceanographic implications. Palaeogeography, Palaeoclimatology, Palaeoecology 297, 537-548.

Stramma, L., Fischer, J., Reppin, J., 1995. The North Brazil Undercurrent. Deep Sea Research Part I: Oceanographic Papers 4, 773-795.

Stute, M., Forster, M., Frischkorn, H., Serejo, A., Clark, J.F., Schlosser, P., Broecker, W.S., Bonani, G., 1995. Cooling of tropical Brazil $\left(5^{\circ} \mathrm{C}\right)$ during the Last Glacial Maximum. Science 269, 39-383.

Thompson, L.G., 2000. Ice core evidence for climate change in the Tropics: implications for our future. Quaternary Science Reviews 19, 19-34.

Thompson, L.G., Davis, M.E., Mosley-Thompson, E., Sowers, T.A., Henderson, K.A., Zagorodnov, V.S., Lin, P.-N., Mikhalenko, V.N., Campen, R.K., Bolzan, J.F., Cole-Dai, J., Francou, B., 1998. A 25, 000-year tropical climate history from Bolivian ice cores. Science 282, 1858-1864.

Thunnell, R., Tappa, E., Pride, C., Kincaid, E. 1999. Sea-surface temperature anomalies associated with the 1997-1998 El Niño recorded in the oxygen isotope composition of planktonic foraminifera. Geology 27, 843-846.
Tian, J., Huang, E., Pak, D.K., 2010. East Asian winter monsoon variability over the last glacial cycle: insights from a latitudinal sea-surface temperature gradient across the South China Sea. Palaeogeography, Palaeoclimatology, Palaeoecology 292, 319-324.

Vink, A., Rühlemann, C., Zonneveld, K.A.F., Mulitza, S., Hüls, M., Willems, H., 2001. Shifts in the position of the North Equatorial Current and rapid productivity changes in the western Tropical Atlantic during the last glacial. Paleoceanography 16, 479-490.

Vink, A., Brune, A., Holl, C., Zonneveld, K.A.F., Willems, H., 2002. On the response of calcareous dinoflagellates to oligotrophy and stratification of the upper water column in the equatorial Atlantic Ocean. Palaeogeography, Palaeoclimatology, Palaeoecology 178, 53-66.

Visser, K., Thunnell, R., Stott, L., 2003. Magnitude and timing of temperature change in the Indo-Pacific warm pool during deglaciation. Nature 421, 152-155.

Wan, X., Chang, P., Saravanan, R., Zhang, R., Schmidt, M.W., 2009. On the interpretation of Caribbean paleo-temperature reconstructions during the Younger Dryas. Geophysical Research Letters 36, L02701 doi:10.1029/2008GL035805, 2009.

Wang, X., Auler, A.S., Edwards, R.L., Cheng, H., Cristalli, P.S., Smart, P.L., Richards, D.A., Shen, C.-C., 2004. Wet periods in northeastern Brazil over the past $210 \mathrm{kyr}$ linked to distant climate anomalies. Nature 432, 740-743.

Wang, S., Lu, H., Han, J., Chu, G., Liu, J., Negendank, J.F.W., 2010. Palaeovegetation and palaeoclimate in low-latitude southern China during the Last Glacial Maximum. Quaternary International doi:10.1016/j.quaint.2010.07.030.

Weldeab, S., Schneider, R., Kölling, M., 2006. Deglacial sea surface temperature and salinity increase in the western tropical Atlantic in synchrony with high latitude climate instabilities. Earth and Planetary Science Letters 241, 699-706.

Wolff, T., Mulitza, S., Arz, H.W., Wefer, G., 1998. Oxygen isotopes versus CLIMAP (18 ka) temperatures: a comparison from the tropical Atlantic. Geology 26, 675-678.

Wolff, T., Grieger, B., Hale, W., Dürkoop, A., Mulitza, S., Pätzold, J., Wefer, G., 1999. On the reconstruction of palaeosalinities. In: Fischer, G., Wefer, G. (Eds.), Use of Proxies in Palaeoceanography: Examples from the South Atlantic. Springer-Verlag, Heidelberg, Germany, pp. 207-228. 